\title{
Measurement of Energy Production from Biogas: Evidence from the Wastewater Treatment Plant in Durres
}

\author{
Stela Sefa, Tania Floqi, Julian Sefa
}

\begin{abstract}
The wastewater treatment plant serving the city of Durres, which is the second most populous city of Albania, employs the tertiary advanced wastewater treatment method and engages in biogas production to achieve energy efficiency. In order to empirically evaluate the plant's energy efficiency realization, the total biogas produced and converted to electricity for daily consumption was measured during a three years period (2016 - 2018). The highest electricity produced was recorded in 2016 , with a daily average of $844 \mathrm{kWh}$ compared to $550 \mathrm{kWh}$ and $370 \mathrm{kWh}$ in 2017 and 2018, respectively. So that the plant meets proper criteria to classify as an energy-efficient entity, 30.0 percent of its electricity consumption must be derived from biogas. Converted in $\mathrm{kWh}$, the plant should generate 2,975 $\mathrm{kWh} / \mathrm{day}$. Based on the biomass and energy values measured during the study period, it is concluded that electricity supplied from biogas met 6.0 percent of the plant's energy requirements, or one fifth of the energy-efficiency target. While the plant was successful in carrying out the full waste-toenergy production process, the electricity supplied from biogas was very low and did not fulfil the plant's self-energy requirements.
\end{abstract}

Index Terms - wastewater treatment plant, biogas, renewable energy, electricity, energy efficiency.

\section{INTRODUCTION}

The wastewater treatment plant subject to this study is located in the city of Durres, Albania (WWTPD). It treats urban wastewater for 205 thousand people living in an area of $432 \mathrm{~m}^{2}$ [1]. Its combined wastewater disposal system handles an average urban water flow of $20,160 \mathrm{~m}^{3} /$ day or 233 1/sec [2]. WWTPD uses the tertiary/advanced wastewater treatment and produces biogas from the residual material originating as a by-product of sewage treatment known as sludge. Specifically, the plant has a production line dedicated to biogas generation via the anaerobic digestion process, which is then transformed to power its own energy grid. From an economic perspective, sludge management and electricity consumption costs are generally considered to constitute a large part of operating expenses related to wastewater treatment. A key challenge for a wastewater plant, therefore, is lowering costs associated with both energy consumption and sludge management without compromising quality standards. For the WWTPD to be completely energyefficient, manual specifications indicate that 30 percent of its electricity power must be supplied from biogas [3].

Published on October 30, 2020.

Stela Sefa, Department of Engineering Science, Faculty of Professional Science, Aleksandër Moisiu University of Durrës, Albania.

(e-mail: stelasefa@gmail.com)
The technology underlying wastewater treatment is wellestablished and proven to be very effective in terms of treating and delivering high quality, high volume reclaimed water. However, the current technology deployed is not energy efficient. Although today there is no specific law or regulatory ruling addressing energy efficiency for integrated hydraulic systems in Albania, it is worth studying the economic impact stemming from self-generated biomass energy. In fact, implementation and adoption of energy efficiency measures in wastewater treatment plants is directly in line with Directive 2009/28/EC [4] of the European Parliament for renewable energy as well as the parameters for quality management systems contained in ISO 95001 [5]. This study's aim is thus to provide reliable estimates of biogas production and energy conversion by WWTPD calculated using scientific methods, estimates which may form a basis for further quantitative research or be used to support future actions and initiatives in the broader sphere of renewable energy in Albania.

\section{MATERIAL AND METHODS}

This study measured the quantity of biogas produced daily from 2016 through 2018 [6][7]. To present energy production findings in meaningful daily average metrics, days with no production were also included in the calculations. In other words, average daily $\mathrm{kWh}$ calculations were calculated as the sum of positive daily production divided by 365 days.

Total biogas was collected from the anaerobic digestion tank and samples were extracted following standards found in ISO/OIS 14853 [8]. Average daily production was measured in $\mathrm{m}^{3} / \mathrm{day}$. Biogas was converted in $\mathrm{kWh}$ as follows: $1 \mathrm{~m}^{3} \mathrm{CH}_{4}$ is equivalent to $9.7 \mathrm{kWh}$ [9]. The plant's equipment installations and systems were measured to consume $9,916 \mathrm{kWh} /$ day energy. For the plant to achieve energy-efficiency, it should produce $2,975 \mathrm{kWh} /$ day from biogas, with the remaining $6,941 \mathrm{kWh} /$ day generated from the electrical grid.

\section{RESULTS}

Based on the measurements made during the study period, WWTPD produced an average of $844.48 \mathrm{kWh} /$ day in 2016. In 2017 energy production values from $\mathrm{CH}_{4}$ declined to $549.92 \mathrm{kWh} /$ day, 35.0 percent lower than the prior year. In a

Tania Floqi, Department of Engineering and Architecture, Faculty of Engineering, Informatics and Architecture, UE Tirana, Albania. (e-mail: floqitania@yahoo.com) Julian Sefa, Environmental Engineer, Durrës, Albania (e-mail: Juliansefa ${ }^{@}$ gmail.com). 
similar trend, 2018 resulted in the lowest energy production level of $369.86 \mathrm{kWh} /$ day, which represents a negative growth of 33.0 percent from the prior year. Translated in energyefficiency percentages, WWTPD met 28.0 percent, 18.0 percent, and 12.0 percent of its energy-sufficiency goal of 2,975 kWh/day from biogas in 2016, 2017, and 2018, respectively. More succinctly, WWTPD generated on average only 6.0 percent energy via biogas during the study period, as compared to the 30.0 percent required amount, thus meeting one-fifth of its energy-efficiency goal.

Table 1 presents the average production values calculated by study year as well as the equivalent amounts in electrical energy for each year.

\begin{tabular}{ccccc}
\multicolumn{2}{c}{ TABLE I: ENERGY PRODUCTION FROM BIOGAS IN 2016, 2017 AND 2018 } \\
\hline \hline Year & $\begin{array}{c}\text { Average daily } \\
\text { biogas } \\
\text { production } \\
\left(\mathrm{m}^{3} / \text { day }\right)\end{array}$ & $\begin{array}{c}\text { Average daily } \\
\text { per year of } \\
\text { methane } \\
\left(\mathrm{m}^{3} \mathrm{CH}_{4} / \text { day }\right)\end{array}$ & $\begin{array}{c}\text { Average } \\
\text { daily per } \\
\text { year } \\
(\mathrm{kWh})\end{array}$ & $\begin{array}{c}\text { Average } \\
\text { daily per } \\
\text { month } \\
(\mathrm{kWh})\end{array}$ \\
\hline 2016 & 1392.95 & 1044.7125 & 10133.71 & 844.4759 \\
2017 & 944.88 & 680.3136 & 6599.042 & 549.9202 \\
2018 & 653.34 & 457.3400 & 4436.180 & 369.6800 \\
\hline \hline
\end{tabular}

In 2016, WWTPD produced a total of $1392.96 \mathrm{~m}^{3}$ of biogas. This low level of production (as measured relative to energy-efficiency benchmarks) resulted primarily from the lack of production during anaerobic digestion tank (AD) charge-discharge periods. In the early months of the year (January-April), there was no biogas production due to AD tank discharge. The purpose of the discharge was to purify the AD tank after methanogenic microorganisms have completed their biogas production cycle in the prior months. All the biologic reactions of anaerobic digestion occur inside a single closed reactor during the phase of production. At the conclusion of the process, it is necessary to sterilize the reactor. In other words, reservoirs are discharged during January and February and then are filled with fresh sewage sludge during March and April to restart the biogas production for the preceding months. Given that AD is itself a continuous process, biomass builds up periodically. The retention period of the sewage mixture in the $\mathrm{AD}$ reactors was measured to range from 20 to 30 days on average. Biogas production commenced at the beginning of May, with daily frequency. The highest amounts produced were during summer, with an average of approximately $256.07 \mathrm{~m}^{3} /$ day. In December, the AD discharge phase was restarted again. So, in 2016 WWTPD did not produce biogas for five months of the year.

In 2017, WWTPD recorded $944.87 \mathrm{~m}^{3}$ biogas production. AD reactor's discharge started in December of 2016 and completed the cycle in January of 2017. The AD reactor was then filled with fresh sludge until March, where it has started the biogas production process. Incoming sludge in the reactor was performed periodically applying a continuous blending process. Retention period in the $\mathrm{AD}$ reactor was approximately 15 days. This subsequently impacted the quantity of biogas produced in comparison to the prior year.

The same charge-discharge procedures were followed by WWTPD in 2018. However, the total cycle was completed in a shorter period of two months. WWTPD produced a total of $653.34 \mathrm{~m}^{3}$ biogas, which is the lowest production level in the study period. The quantity of fresh sludge loaded in the AD reactor was higher than the previous years, which negatively impacted $\mathrm{pH}$ levels. A large quantity of sludge and a short retention period resulted in lower biogas production.

The graph below summarizes $\mathrm{CH}_{4}$ production in $\mathrm{m}^{3}$, converted in $\mathrm{kWh}$ by year.

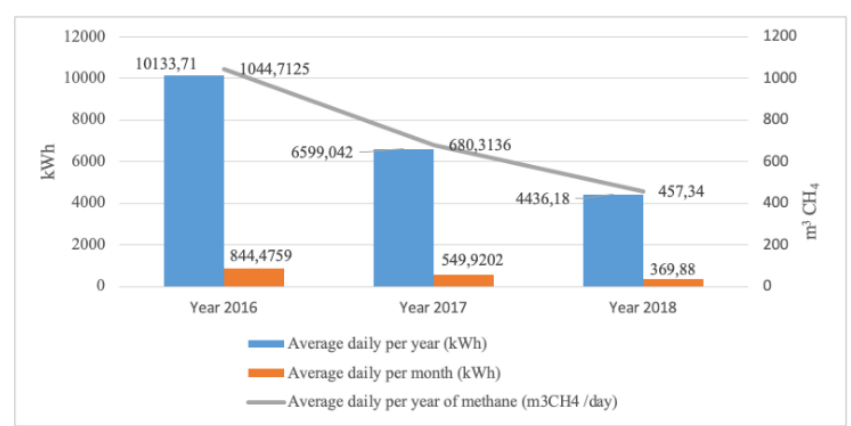

Graph. 1. Production of energy in $\mathrm{kWh}$ in relation to $\mathrm{CH}_{4}$.

\section{CONCLUSION}

The deployed technology to produce biogas from wastewater treatment plant generated positive results, meaning the plant was able to extract electricity from wastewater treatment by-products (sludge) which in turn was used for self-energy consumption.

During a study period of three years the Wastewater Treatment Plant in Durres has produced an average of electricity $844.48 \mathrm{kWh}$ per day for $2016,549.92 \mathrm{kWh}$ for 2017 and $369.68 \mathrm{kWh}$ for 2018.

However, the WWTPD has not fulfilled 30 percent of energy needs according to the Technology Manual.

To understand what caused low production of biogas from WWTPD's sludge, it was important to study the overall sludge quality, total quantity, and the process employed by the plant to manage the anaerobic digestion process.

\section{REFERENCES}

[1] http://www.akm.gov.al/assets/impianti-i-duresit.pdf.

[2] https://www.shuk.al/durres.

[3] Operation and Maintenance Manual of Wastewater Treatment Plant Durres, May 2011.

[4] Directive 2009/28/EC "On the promotion of the use of energy from renewable sources". http://eur-lex.europa.eu/legalcontent/IT/ALL/?uri=CELEX\%3A32009L0028.

[5] ISO 9001:2015 "Quality management systems - Requirements".

[6] Yunus A. Çengel, Michael A. Boles "Thermodynamic - 7th Edition".

[7] M. Walker, Y. Zhang, S. Heaven, C. Banks, "Potential errors in the quantitative evaluation of biogas production in anaerobic digestion processes," Bioresource Technology, Vol. 100, 2009. G. O. Young, "Synthetic structure of industrial plastics," in Plastics, 2nd ed. vol. 3, J. Peters, Ed. New York: McGraw-Hill, 1964, pp. 15-64.

[8] ISO/OIS 14853 "Determination of Anaerobic digestion".

[9] Stefano Marzorati, 2016 web: http://marzorati.co/quanti-kwh-permetro-cubo-di-metano/. 


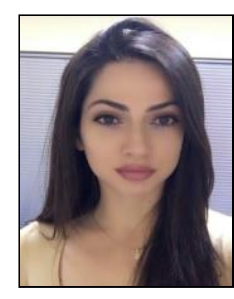

Mrs. Stela Sefa was born in Durres, Albania. She holds Master in Science degree from the Faculty of Civil Engineering at the Polytechnic University of Tirana. In 2020 she completed the PhD Program in Environmental Engineering profile with her thesis "Aspects of biomass and energy production in Wastewater Treatment Plant of Durres".

Since 2009 she is a lecturer at the Faculty of Professional Studies at "Aleksandër Moisiu" University of Durrës. In 2013 she completed a biogas specialization at the University of Applied Sciences in Bremen, Germany. Mrs. Sefa is author and co-author of scientific articles in engineering sciences and participating in national and international conferences. 